\title{
Regional Disparities of Facility-Based Childbirth in Indonesia
}

\author{
Agung Dwi Laksono ${ }^{1}$ and Ratna Dwi Wulandari, ${ }^{2, *}$ \\ ${ }^{I}$ National Institute of Health Research and Development, MOH of the Republic of Indonesia, \\ Jakarta, Indonesia \\ ${ }^{2}$ Faculty of Public Health, Universitas Airlangga, Campus C Mulyorejo, Surabaya, Indonesia
}

('Corresponding author's e-mail: ratna-d-w@fkm.unair.ac.id)

Received: 29 July 2020, Revised: 7 May 2021, Accepted: 17 May 2021

\begin{abstract}
Specifically, the characteristics of regions in Indonesia are unique. The situation is because the division of the region refers to the main islands. The study aims to analyze regional disparities of childbirth services in Indonesia. Meanwhile, the analysis in this study uses raw data from the 2017 Indonesian Demographic Health Survey (IDHS). The IDHS used stratification and multistage random sampling. The sample used in this study was 17,769 women aged 15 - 49 years with live births in the last 5 years. The study employed all region ( 7 regions) in the analysis, and analyzed data using the binary logistic regression test. The result shows national average of the utilization of healthcare facilities for delivery in Indonesia is $72.0 \%$. The 3 highest-ranking regions were in the Java-Bali region with $89.5 \%$, Sumatra region $73.5 \%$, and Kalimantan region $69.1 \%$. The study shows a significant disparity between all regions than the Papua region, except for Kalimantan and Sulawesi regions. Sumatra region has 1.475 times more possibilities to utilize healthcare facilities for delivery than the Papua region. The Java-Bali region has 3.010 times more potential to use healthcare facilities for delivery than the Papua region. The Nusa Tenggara region has 1.891 times more opportunities to use healthcare facilities for delivery than the Papua region. At the same time, the Maluku region has lower utilization than the Papua region. Maluku region has the possibility of 0.304 times utilizing healthcare facilities for delivery than the Papua region. The study concluded that there were significant disparities between regions in using healthcare facilities for delivery in Indonesia.
\end{abstract}

Keywords: Childbirth, Regional disparities, Healthcare evaluation, Maternal health, Indonesia

\section{Introduction}

Indonesia has made many efforts in shifting labor into health care facilities. The Indonesia Basic Health Survey (Riskesdas) in 2007, 2013, and 2018 also recorded the condition, which is always better than the previous period [1]. Although this increase is still lacking, and in some cases, the community still feels that the health services received are not expected [2].

Studies in various countries on disparities in the use of health services focus on the study of disparities between urban and rural areas. Research facts show significant differences between the 2 regions [3-5]. A previous study reported that young women in urban Indonesia were 2.23 times more likely to attend healthcare childbirth than those in rural Indonesia [6]. Meanwhile, other studies report that at least 6 factors were identified as barriers to the utilization of healthcare facilities for delivery in rural Indonesia. These 6 factors were low education, high parity, poverty, not having health insurance, not knowing the danger signs of pregnancy, and ANC $<4$ times [7]. Based on these findings, we assumed that if a region has many urban areas, it has better utilization of health services than areas dominated by rural areas.

The Indonesian government has released a National Health Insurance policy to reduce the barrier to service costs for the public to access health services, including delivery services to health facilities [8]. The policy has proven to encourage women in Indonesia to deliver delivery to health care facilities. At least, women who were covered by health insurance are 1.138 times more likely to deliver in healthcare facilities than women who are not covered by health insurance [9].

Specifically, the characteristics of regions in Indonesia are unique. The condition is because the division of the area refers to the main islands. The situation is motivated by Indonesia's geographical 
conditions in the form of islands. The United Nations Group of Experts on Geographical Names (UNGEGN) from the United Nations verified Indonesia consists of at least 16,056. This amount is part of the total 17,504 islands that are owned by Indonesia [10].

Economic and development movements between regions keep the development gap between regions continuing. Disparity as a result of this development also affects the accessibility of the community to health service facilities. Regions with good economic movements tend to have good health service facility accessibility [10]. Previous studies that analyzed regional disparities in the use of health services reported that this condition still exists. All regions showed better utilization than the Papua region as a reference. The Papua region is the easternmost region in Indonesia. The best utilization was in the Sumatra region (westernmost region), which was 3.781 times more utilizing health centers than the Papua region [10].

Reducing disparities in realizing health services in universal deliveries is the goal of health policymakers [11]. Based on the background narration, do regional disparities in childbirth services in Indonesia? The study aims to analyze the regional disparity of childbirth services in Indonesia. The results of this study's analysis are helpful for policymakers to ensure equal delivery of services between regions.

\section{Materials and methods}

\section{Data source}

The analysis in this study uses raw data from the 2017 Indonesian Demographic Data Survey (IDHS). The IDHS was part of the international Demographic and Health Survey (DHS) program conducted by the Inner City Fund (ICF). In Indonesia, the Central Statistics Agency collaborated with the National Population and Family Planning Board (BKKBN) and the Ministry of Health to carry out the 2017 IDHS.

The study used stratification and multistage random sampling in the selection of the 2017 IDHS sample. The 2017 IDHS surveyed 34 provinces in Indonesia. The samples used in this study were women aged 15 - 49 years old who had given birth in the last 5 years. The sample size of the 2017 IDHS used in this analysis was 17,769 women.

\section{Variables}

The study grouping the regions based on the geographical location of the province. The regions consists of 7 regions, namely Sumatra, Kalimantan, Sulawesi, Java-Bali, Maluku Islands, Nusa Tenggara, and Papua [12]. Deliveries performed in health care facilities include healthcare centers (Puskesmas), clinics or maternity hospitals, practices of health workers, and hospitals [13].

Variables analyzed included residence, age, education level, work status, marital status, parity, wealth status, cover by health insurance, the autonomy of family finances, the autonomy of health, knowledge the danger signs of pregnancy, and antenatal care. The residence type consists of 2 categories, namely urban and rural. The urban-rural criteria refer to Statistics Indonesia. The study determine age based on the last birthday. Education level is the respondent's recognition of the last diploma they have. Education level is divided into 4 categories: no education, primary, secondary, and higher. Work status consists of 2 types: no work and work. Marital status consists of 2 categories: Single and married/living with a partner. Meanwhile, parity was a live-born baby who has been born.

The IDHS determined wealth status based on the quintile of wealth owned by a household. Households were scored based on the number and type of items they have, from televisions to bicycles or cars, and housing characteristics, such as drinking water sources, toilet facilities, and primary building materials for the house's floor. This score calculated using principal component analysis. National wealth quintiles were arranged based on household scores for each person in the household and then divided by the distribution into the same 5 categories, accounting for $20 \%$ of the population. The wealth status consists of 5 categories: the poorest, poorer, middle, richer, and the richest [14].

Covered by health insurance consists of 2 types: No and yes. Know of pregnancy danger signs was defined as knowledge of dangers of prolonged labor, vaginal bleeding, fever, convulsions, breech position, swollen limbs, faint, breathlessness, tiredness, and others. The knowledge of danger signs of pregnancy consists of 2 categories: do not know and know. Respondents were considered "know" when they claimed to know all pregnancy danger signs.

The autonomy of family finance describes respondents' independency to allocate money on family financial resources. The autonomy of family finances has 2 categories: No and yes. The autonomy of 
health is the independence to determine the needs of health services. The autonomy of health has 2 categories: no and yes.

The Ministry of Health of the Republic of Indonesia recommends that the ANC during pregnancy be performed at least for times, namely, 1 time in the $1^{\text {st }}$ trimester, 1 time in the $2^{\text {nd }}$ trimester, and 2 times in the $3^{\text {rd }}$ trimester [15]. ANC visits consists of 2 categories: $<4$ times and $\geq 4$ times.

\section{Data analysis}

The study carried out statistical analysis using Chi-Square for dichotomous variables and t-test for continuous variables. The research carried out statistical analysis to assess whether there were statistically significant differences in delivery services between regions. The study performed estimates using binary logistic regression because of the nature of the dependent variable. The author carried out all statistical analyses using IBM SPSS 21 software.

\section{Ethical approval}

The 2017 IDHS has obtained ethical approval from the National Institute for Health Research and Development of the Indonesian Ministry of Health. The IDHS deleted all the respondents' identities from the dataset. Respondents have provided written approval for their involvement in the study. The use of the 2017 IDHS data for this study has received permission from ICF International through its website: https://dhsprogram.com/data/new-user-registration.cfm.

\section{Results and discussion}

Figure 1 displays the distribution of childbirth coverage to healthcare facilities in 34 provinces in Indonesia. In the eastern region, Maluku and Papua, the scope of delivery to health service facilities is lower than in other areas. In comparison, the Java-Bali region has the highest coverage of deliveries to healthcare facilities than other regions in Indonesia.

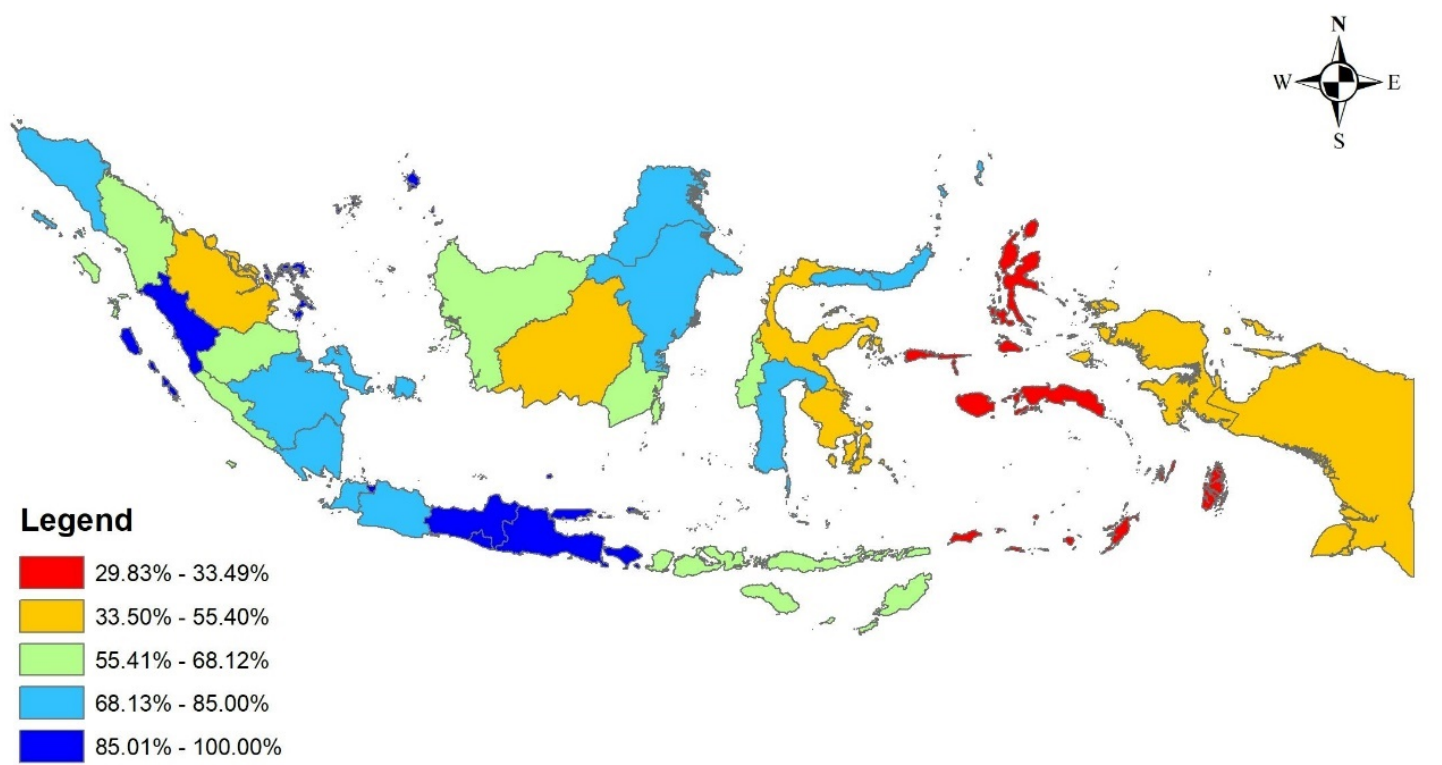

Figure 1 Distribution of childbirth coverage to healthcare facilities in 34 provinces, Indonesia (IDHS 2017).

The study performed a co-linearity test in the $1^{\text {st }}$ step before carrying out a multinomial logistic regression test. Co-linearity test results are shown in Table $\mathbf{1}$ that there is no co-linearity between the dependent and independent variables. 
Table 1 Results for the co-linearity test of facility-based childbirth in Indonesia.

\begin{tabular}{lcc}
\hline \multicolumn{1}{c}{ Variables } & \multicolumn{2}{c}{ Collinearity Statistics } \\
\cline { 2 - 3 } & Tolerance & VIF \\
\hline Region & 0.896 & 1.116 \\
Place of Residence & 0.765 & 1.308 \\
Age & 0.582 & 1.717 \\
Education level & 0.713 & 1.403 \\
Work status & 0.934 & 1.071 \\
Marital status & 0.814 & 1.229 \\
Parity & 0.530 & 1.886 \\
Wealth status & 0.587 & 1.704 \\
Health insurance & 0.961 & 1.041 \\
The autonomy of family finances & 0.795 & 1.259 \\
The autonomy of health & 0.718 & 1.393 \\
Know the dangers signs of pregnancy & 0.894 & 1.119 \\
Antenatal care & 0.881 & 1.135 \\
\hline
\end{tabular}

*Dependent variable: Childbirth services.

Table 1 shows that the tolerance value of all variables is more significant than 0.10 . Meanwhile, the VIF value for all variables is less than 10.00. The study inferred no signs of correlation between 2 independent variables in the regression model based on decision-making in the multicollinearity test.

The national average of the utilization of healthcare facilities for delivery in Indonesia is $72.0 \%$. Meanwhile, the 3 highest-ranking regions are in the Java-Bali region with $89.5 \%$, Sumatra region 73.5 $\%$, and Kalimantan region $69.1 \%$.

Table 2 shows differences between regions in the utilization of healthcare facilities for delivery for all observed statistically significant characteristics. Women who use healthcare facilities for delivery are more dominant than those who deliver at nonhealthcare facilities in all regions. The woman who has given birth in the last 5 years in Indonesia predominantly lives in rural areas, except in the Java-Bali and Kalimantan regions that exist in urban areas.

Meanwhile, Table 2 informs that the average woman living in the Nusa Tenggara region is slightly older than other areas. Indonesian women with secondary education and had marital status married in all areas occupied women who gave birth in the last 5 years. In the previous 5 years, women who gave birth in Indonesia were prevalent who did not work, except for the Papua region, where women worked more dominantly. Women who live in the Papua region have an average parity higher than in other areas. Table 2 shows that women who gave birth in the last 5 years in Indonesia were ruled by the poorest women, except in the Java-Bali and Kalimantan regions. Overall, in all areas, women who gave birth in the last 5 years in Indonesia predominantly have health insurance.

Table 2 informs that women with autonomy over their family finances and health occupied women have given birth in the last 5 years in Indonesia. In all regions, women who knew about the danger signs of pregnancy ruled women who gave birth in the previous 5 years in Indonesia, except in the Maluku and Papua regions. Overall, women who gave birth in the last 5 years in Indonesia predominantly had antenatal care more than 4 times before giving birth. 
https://doi.org/10.48048/tis.2021.387

Table 2 Descriptive Statistic of Socio-demographic characteristics of childbirth services in Indonesian regions $(\mathrm{n}=17,769)$.

\begin{tabular}{|c|c|c|c|c|c|c|c|c|c|}
\hline \multirow[b]{2}{*}{ Characteristics } & \multicolumn{7}{|c|}{ REGION } & \multirow[b]{2}{*}{ ALL } & \multirow[b]{2}{*}{$\mathbf{P}$} \\
\hline & $\begin{array}{l}\text { Sumatera } \\
(n=4705)\end{array}$ & $\begin{array}{l}\text { Java-Bali } \\
(\mathrm{n}=\mathbf{5 3 5 3}) \\
\end{array}$ & $\begin{array}{c}\text { Nusa Tenggara } \\
(n=1534)\end{array}$ & $\begin{array}{c}\text { Kalimantan } \\
(n=1630)\end{array}$ & $\begin{array}{c}\text { Sulawesi } \\
(\mathrm{n}=\mathbf{2 7 1 6}) \\
\end{array}$ & $\begin{array}{c}\text { Maluku Islands } \\
(n=1258)\end{array}$ & $\begin{array}{c}\text { Papua } \\
(n=573)\end{array}$ & & \\
\hline Place of Delivery & & & & & & & & & 0.000 \\
\hline $\begin{array}{l}\text { - Nonhealthcare } \\
\text { Facilities }\end{array}$ & $1247(25.50 \%)$ & $562(10.50 \%)$ & $518(33.77 \%)$ & $504(30.92 \%)$ & $985(36.27 \%)$ & $867(68.92 \%)$ & $287(50.09 \%)$ & $4970(27.97 \%)$ & \\
\hline $\begin{array}{l}\text { - Healthcare } \\
\text { Facilities }\end{array}$ & $3458(73.50 \%)$ & $4791(89.50 \%)$ & $1016(66.23 \%)$ & $1126(69.08 \%)$ & $1731(63.73 \%$ ), & $391(31.08 \%)$ & $286(49.91 \%)$ & $12799(72.03 \%)$ & \\
\hline $\begin{array}{l}\text { Place of } \\
\text { Residence }\end{array}$ & & & & & & & & & 0.000 \\
\hline - Urban & $2131(45.29 \%)$ & $3668(68.52 \%)$ & $451(29.40 \%)$ & $865(53.07 \%)$ & 1018 (37.48 \%), & $457(36.33 \%)$ & $133(23.21 \%)$ & $8723(49.09 \%)$ & \\
\hline - Rural & $2574(54.71 \%)$ & $1685(31.48 \%)$ & $1083(70.60 \%)$ & $765(46.93 \%)$ & 1698 (62.52\%), & $801(63.67 \%)$ & $440(76.79 \%)$ & $9046(50.91 \%)$ & \\
\hline Age (mean) & 4705 (31.07) & $5353(30.91)$ & $1534(31.31)$ & $1630(30.54)$ & $2716(30.51)$ & $1258(30.71)$ & $573(30.10)$ & $17769(30.85)$ & 0.000 \\
\hline Education level & & & & & & & & & 0.000 \\
\hline - No education & $54(1.15 \%)$ & $24(0.45 \%)$ & $73(4.76 \%)$ & $18(1.10 \%)$ & $43(1.59 \%)$ & $10(0.79 \%)$ & $47(8.20 \%)$ & $269(1.51 \%)$ & \\
\hline - Primary & $1026(21.08 \%)$ & $1281(23.93 \%)$ & $526(34.29 \%)$ & $452(27.73 \%)$ & $748(27.54 \%)$ & $278(22.10 \%)$ & $120(20.94 \%)$ & $4431(24.94 \%)$ & \\
\hline - Secondary & $2650(56.32 \%)$ & $3258(60.86 \%)$ & $706(46.02 \%)$ & $904(55.46 \%)$ & 1345 (49.52 \%), & $718(57.07 \%)$ & $298(52.01 \%)$ & $9879(55.60 \%)$ & \\
\hline - Higher & $975(20.72 \%)$ & $790(14.76 \%)$ & $229(14.93 \%)$ & $256(15.71 \%)$ & $580(21.35 \%)$ & $252(20.03 \%)$ & $108(18.85 \%)$ & $3190(17.95 \%)$ & \\
\hline Work status & & & & & & & & & 0.000 \\
\hline - No work & $2441(51.88 \%)$ & $3031(56.62 \%)$ & $773(50.39 \%)$ & $860(52.76 \%)$ & 1445 (53.20\%), & $682(54.21 \%)$ & $252(43.98 \%)$ & $9484(53.37 \%)$ & \\
\hline - Work & $2264(48.12 \%)$ & $2322(43.38 \%)$ & $761(49.61 \%)$ & $770(47.24 \%)$ & $1271(46.80 \%$ ), & $576(45.79 \%)$ & $321(56.02 \%)$ & $8285(46.63 \%)$ & \\
\hline Marriage status & & & & & & & & & 0.000 \\
\hline - Never married & $0(0.00 \%)$ & $0(0.00 \%)$ & $20(1.30 \%)$ & $1(0.06 \%)$ & $0(0.00 \%)$ & $5(0.40 \%)$ & $3(0.52 \%)$ & $29(0.16 \%)$ & \\
\hline - Married & $4572(97.17 \%)$ & $5211(97.35 \%)$ & $1450(94.52 \%)$ & $1581(97.00 \%)$ & 2638 (97.13 \%) & $1220(96.98 \%)$ & $540(94.24 \%)$ & $17212(97.87 \%)$ & \\
\hline - Divorced & $133(2.83 \%)$ & $142(2.65 \%)$ & $64(4.17 \%)$ & $48(2.94 \%)$ & $78(2.87 \%)$ & $33(2.62 \%)$ & $30(5.24 \%)$ & $528(2.97 \%)$ & \\
\hline Parity (mean) & $4705(2.53)$ & $5353(2.14)$ & $1534(2.81)$ & $1630(2.48)$ & $2716(2.65)$ & $1258(2.96)$ & $573(3.34)$ & $17769(2.51)$ & 0.000 \\
\hline Wealth status & & & & & & & & & 0.000 \\
\hline - Poorest & $1060(22.53 \%)$ & $521(9.73 \%)$ & $956(62.32 \%)$ & $323(19.82 \%)$ & 1019 (37.52 \%), & $732(58.19 \%)$ & $322(56.20 \%)$ & $4933(27.76 \%)$ & \\
\hline - Poorer & $1013(21.53 \%)$ & $888(16.59 \%)$ & $278(18.12 \%)$ & $363(22.27 \%)$ & $602(22.16 \%)$ & $229(18.20 \%)$ & $97(16.93 \%)$ & $3470(19.53 \%)$ & \\
\hline - Middle & $981(20.85 \%)$ & $1135(21.20 \%)$ & $134(8.74 \%)$ & $386(23.68 \%)$ & $409(15.06 \%)$ & $135(10.73 \%)$ & $68(11.87 \%)$ & $3248(18.28 \%)$ & \\
\hline - Richer & $869(18.47 \%)$ & $1378(25.74 \%)$ & $89(5.80 \%)$ & $290(17.79 \%)$ & $326(12.00 \%)$ & $120(9.54 \%)$ & $50(8.73 \%)$ & $3122(17.57 \%)$ & \\
\hline - Richest & $782(16.62 \%)$ & $1431(26.73 \%)$ & $77(5.02 \%)$ & $268(16.44 \%)$ & $360(13.25 \%)$ & $42(3.34 \%)$ & $36(6.28 \%)$ & $2996(16.86 \%)$ & \\
\hline $\begin{array}{l}\text { Covered by } \\
\text { health insurance }\end{array}$ & & & & & & & & & 0.000 \\
\hline - No & $1697(36.07 \%)$ & $2152(40.20 \%)$ & $589(38.40 \%)$ & $711(43.62 \%)$ & $839(30.89 \%)$ & $586(46.58 \%)$ & $127(22.16 \%)$ & $6701(37.71 \%)$ & \\
\hline - Yes & $3008(63.93 \%)$ & $3201(59.80 \%)$ & $945(61.60 \%)$ & $919(56.38 \%)$ & 1877 (69.11\%), & $672(53.42 \%)$ & $446(77.84 \%)$ & $11068(62.29 \%)$ & \\
\hline $\begin{array}{l}\text { The autonomy of } \\
\text { family finances }\end{array}$ & & & & & & & & & 0.000 \\
\hline - No & $1374(29.20 \%)$ & $1497(27.97 \%)$ & $354(23.08 \%)$ & $429(26.32 \%)$ & $486(17.89 \%)$ & $257(20.43 \%)$ & $214(37.35 \%)$ & $4611(25.95 \%)$ & \\
\hline - Yes & $3331(70.80 \%)$ & $3856(72.03 \%)$ & $1180(76.92 \%)$ & $1201(73.68 \%)$ & $2230(82.11 \%$ ) & $1001(79.57 \%)$ & $359(62.65 \%)$ & $13158(74.05 \%)$ & \\
\hline $\begin{array}{l}\text { The autonomy of } \\
\text { health }\end{array}$ & & & & & & & & & 0.000 \\
\hline - No & $734(15.60 \%)$ & $716(13.38 \%)$ & $230(14.99 \%)$ & $216(13.25 \%)$ & $288(10.60 \%)$ & $163(12.96 \%)$ & $71(12.39 \%)$ & $2418(13.61 \%)$ & \\
\hline - Yes & $3971(84.40 \%)$ & $4637(86.62 \%)$ & $1304(85.01 \%)$ & $1414(86.75 \%)$ & 2428 (89.40 \%) & $1095(87.04 \%)$ & $502(87.61 \%)$ & $15351(86.39 \%)$ & \\
\hline Know the danger & ns of pregnancy & & & & & & & & 0.000 \\
\hline - No & $1757(37.34 \%)$ & $1311(24.49 \%)$ & $643(41.92 \%)$ & $652(40.00 \%)$ & $951(35.01 \%)$ & $681(54.13 \%)$ & $369(64.40 \%)$ & $6364(35.82 \%)$ & \\
\hline - Yes & $2948(62.66 \%)$ & $4042(75.51 \%)$ & $891(58.08 \%)$ & $978(60.00 \%)$ & 1765 (64.99\%), & $577(45.87 \%)$ & $204(35.60 \%)$ & $11405(64.18 \%)$ & \\
\hline Antenatal care & & & & & & & & & 0.000 \\
\hline$-<4$ times & $1289(27.40 \%)$ & $748(13.97 \%)$ & $364(23.73 \%)$ & $361(22.15 \%)$ & $735(27.06 \%)$ & $481(38.24 \%)$ & $261(45.55 \%)$ & $4239(23.86 \%)$ & \\
\hline$-\geq 4$ times & $3416(72.60 \%)$ & $4605(86.03 \%)$ & $1170(76.27 \%)$ & $1269(77.85 \%)$ & 1981 (72.94\%), & $777(61.76 \%)$ & $312(54.45 \%)$ & $13530(76.15 \%)$ & \\
\hline
\end{tabular}

Note: The study used the Chi-Square test for dichotomous variables; T-test for continuous variables. 
https://doi.org/10.48048/tis.2021.387

Table 3 displays the results of binary logistic regression tests to illustrate disparities between regions in the utilization of healthcare facilities for delivery. As a reference, the chosen category is "nonhealthcare facilities." Table 3 shows the significant disparities between all regions compared to the Papua region, except the Kalimantan and Sulawesi regions, which have no considerable contrast than the Papua region.

Table 3 Binary logistic regression of the use of healthcare facilities for delivery in Indonesia $(\mathrm{n}=$ 17,769).

\begin{tabular}{|c|c|c|c|}
\hline \multirow{3}{*}{ Predictor } & \multicolumn{3}{|c|}{ Healthcare Facilities } \\
\hline & \multirow{2}{*}{ OR } & \multicolumn{2}{|c|}{$95 \%$ CI } \\
\hline & & Lower Bound & Upper Bound \\
\hline Region: Sumatera & $* * * 1.475$ & 1.198 & 1.815 \\
\hline Region: Java-Bali & $* * * 3.010$ & 2.410 & 3.759 \\
\hline Region: Nusa Tenggara & $* * * 1.891$ & 1.508 & 2.372 \\
\hline Region: Kalimantan & 1.085 & 0.862 & 1.365 \\
\hline Region: Sulawesi & 1.096 & 0.886 & 1.355 \\
\hline Region: Maluku Islands & $* * * 0.304$ & 0.240 & 0.385 \\
\hline Region: Papua & - & - & - \\
\hline Place of Residence: Urban & $* * * 2.394$ & 2.189 & 2.618 \\
\hline Place of Residence: Rural & - & - & - \\
\hline Age & $* * * 1.033$ & 1.025 & 1.041 \\
\hline Education level: No education & - & - & - \\
\hline Education level: Primary & $* * 1.524$ & 1.132 & 2.052 \\
\hline Education level: Secondary & $* * * 2.552$ & 1.893 & 3.441 \\
\hline Education level: Higher & $* * * 3.050$ & 2.214 & 4.201 \\
\hline Work status: Work & 0.976 & 0.900 & 1.058 \\
\hline Marriage status: Never Married & 1.811 & 0.752 & 4.360 \\
\hline Marriage status: Married & 0.971 & 0.758 & 1.244 \\
\hline Marriage status: Divorced & - & - & - \\
\hline Parity & $* * * 0.834$ & 0.807 & 0.863 \\
\hline Wealth status: Poorest & - & - & - \\
\hline Wealth status: Poorer & $* * * 1.629$ & 1.467 & 1.809 \\
\hline Wealth status: Middle & $* * * 2.116$ & 1.875 & 2.388 \\
\hline Wealth status: Richer & $* * * 2.292$ & 1.996 & 2.632 \\
\hline Wealth status: Richest & $* * * 4.265$ & 3.545 & 5.130 \\
\hline Covered by health insurance: No & - & - & - \\
\hline Covered by health insurance: Yes & $* * * 1.443$ & 1.332 & 1.564 \\
\hline The autonomy of Family Finances: No & - & - & - \\
\hline The autonomy of Family Finances: Yes & 1.013 & 0.917 & 1.120 \\
\hline The autonomy of Health: No & - & - & - \\
\hline The autonomy of Health: Yes & $* * * 1.061$ & 0.929 & 1.212 \\
\hline Know the danger signs of pregnancy: No & - & - & - \\
\hline Know the danger signs of pregnancy: Yes & $* * * 1.329$ & 1.226 & 1.441 \\
\hline Antenatal care: $<4$ times & - & - & - \\
\hline Antenatal care: $\geq 4$ times & $* * * 1.638$ & 1.498 & 1.792 \\
\hline
\end{tabular}

Note: $* * * p<0.001$. 
Table 3 shows that the Sumatra region has the possibility of 1.475 times more utilizing healthcare facilities for delivery than the Papua region (OR 1.475; $95 \%$ CI 1.198 - 1.815). The Java-Bali region has a 3.010 times possibility of utilizing healthcare facilities for delivery than the Papua region (OR 3.010; 95 \% CI 2.410 - 3.759). The Nusa Tenggara Region has 1.891 times more opportunities to use healthcare facilities for delivery than the Papua region (OR 1.891; $95 \%$ CI 1.508 - 2.372). At the same time, the Maluku region has lower utilization than the Papua region. Maluku Region has the possibility of 0.304 times utilizing healthcare facilities for delivery compared to the Papua region (OR 0.304; $95 \%$ CI 0.240 $0.358)$.

The results found disparities between regions in the utilization of healthcare facilities by maternity mothers in Indonesia. Indonesia's extreme topographic condition, Indonesia's geography, which consists of more than 16 thousand islands, and development disparity between urban and rural areas $[3,16]$, can explain the finding [17].

The utilization of health care facilities for childbirth in the West tends to be better than in the East. This condition is in line with the development process in Indonesia, which also tends to show disparities between the West and East regions. In the West, we felt the development process better than in the East [18-20]. This condition includes the development of overall public health [15,21]. Other studies in several countries also found the same results [22-24]. This study proves that spatially, geographical conditions in an area contribute to creating disparities between regions, including in childbirth services in health care facilities.

Not only in Indonesia, disparities between regions also occur in Iran. A study on finding a regional difference in Iran on obstetrics and gynecology services and its association with children and infants mortality rates. In the final section, this study recommends facilitating the accessibility of the required services for women, particularly those of reproductive age [25]. Other studies have found that regional disparity in Iran also occurs in cataract surgery services [26] and Iranian children and adolescents [27]. Regional differences in Iran may occur due to the unequal input of health resources between regions [2830].

Understanding the etiology of disparities between regions in health services for childbirth is considered essential to improve health services in all communities. The disparities analysis between regions aims to provide clear directions, which every policymaker in the local region can utilize, to improve the quality of childbirth services for women in their area [11,31,32]. In Korea, the local government recognizes the disparity in health services in neonatal health facilities, equipment, and outcomes. The study found the number of high-risk neonates has increased in Korea. Local hospitals are reluctant to open Neonatal Intensive Care Units (NICU) because of low medical expense claims. The Korean government then issued a policy to invest in existing deficiencies, the information obtained from previous studies, and disparities between regions. The impact shows satisfactory results; the gap between areas decreases, as evidenced by the odds ratio for mortality between regions which reduces compared to the previous period [33]. There are other effective ways to increase the scope of health service utilization by being proactive. Health workers make home visits for antenatal care to pregnant women while motivating them to deliver healthcare facilities [34]. This method shows positive results in Ethiopia [35], including involving the husband in communication about childbirth [36,37].

The Indonesian government has issued several policies to reduce disparities between regions in access to health care facilities. The government is developing several health services to reach several areas in eastern Indonesia that have limited access. Some of these innovations are a mobile hospital, flying doctor, sea ambulance, as well as a special budget policy for the Papua region [38-40].

In addition to disparities between regions, the study also found 9 other factors to be meaningful utilization of healthcare facilities for delivery. The 9 determinants are residence, age, education level, parity, wealth status, insurance, the autonomy of health, know the danger signs of pregnancy, and antenatal care. Table 3 informs that women who live in urban areas are 2.394 times more likely to use healthcare facilities for delivery than those who live in rural areas (OR 2.394; 95 \% CI 2.189 - 2.618). Women with higher education are 3,050 times more likely to use healthcare facilities for delivery than those who do not attend school (OR 3.050; $95 \%$ CI $2.214-4.201$ ).

The higher the education level of women, the more efforts to give birth to health care facilities. We found the condition directly proportional to wealth status, the autonomy of health, and knowledge of the danger signs of pregnancy. Previous studies found the better education for women, the better the wealth status, the more understanding the dangerous signs of pregnancy, the more independent in deciding about their health, and the more willing they to use health care facilities in childbirth [41-43] Several previous studies informed that education is a positive determinant of health sector performance output [44-47]. 
Otherwise, several previous studies informed poor education as a barrier to achieving better performance in the health sector $[7,48-50]$.

Table 3 shows that the richest women are 4.265 times more likely to use healthcare facilities for delivery than the poorest women (OR 4.265; $95 \%$ CI $3.545-5.130$ ). Women covered by health insurance had 1.443 times more chance of utilizing healthcare facilities for delivery than those not covered by insurance (OR 1.443; 95 \% CI 1.332 - 1.564). Finally, Table 3 informs that women who have health autonomy are 1.061 times more likely to use healthcare facilities for delivery than those who do not have autonomy of health (OR 1.061; $95 \%$ CI 0.929 - 1.212). Women who did antenatal care $\geq 4$ times had a 1.638 times more chance of utilizing healthcare facilities for delivery than those who did antenatal care $<$ 4 times (OR 1.638; $95 \%$ CI 1.498 - 1.792).

A study of the effects of health insurance ownership in several countries found an increase in the utilization of higher health services [51,52] This condition also applies to the health system in Indonesia $[3,20]$. This condition applies to the use of childbirth services and antenatal care services $[6,52]$.

The government may issue a policy to subsidize labor costs in the previous period (Jampersal) for equitable health service facilities. But when the government gives the policy to provide subsidies for maternity costs, all maternity mothers should have equal access to health care facilities [53]. This study has the limitation of only being able to detect superficial disparities that apply across regions. More indepth studies are needed to explain how this gap can occur.

\section{Conclusions}

The study results concluded that significant disparities exist between regions in utilizing healthcare facilities for delivery in Indonesia. The Sumatra, Java-Bali, and Nusa Tenggara regions have better utilization of healthcare facilities for delivery than the Papua region. Kalimantan and Sulawesi regions utilize healthcare facilities for delivery that is not different from the Papua region. At the same time, the Maluku region has lower utilization of healthcare facilities than the Papua region.

\section{Acknowledgements}

The author would like to thank ICF International, who has agreed to allow the author analyzed the 2017 IDHS data in this article.

\section{References}

[1] National Institute of Health Research and Development of The Indonesia Ministry of Health. The 2018 Indonesia Basic Health Survey (Riskesdas): National report. Jakarta, Indonesia, 2019.

[2] H Megatsari, AD Laksono, IA Ridlo, M Yoto and AN Azizah. Community perspective about health services access. Bull. Health Syst. Res. 2018; 21, 247-53.

[3] AD Laksono, RD Wulandari and O Soedirham. Urban and rural disparities in hospital utilization among Indonesian adults. Iran. J. Publ. Health 2019; 48, 247-55.

[4] D Kenea and H Jisha. Urban-rural disparity and determinants of delivery care utilization in Oromia region, Ethiopia: Community-based cross-sectional study. Int. J. Nurs. Pract. 2017; 23, e12510.

[5] J Li, L Shi, H Liang, G Ding and L Xu. Urban-rural disparities in health care utilization among Chinese adults from 1993 to 2011. BMC Health Serv. Res. 2018; 18, 102.

[6] AD Laksono, RD Wulandari and R Rukmini. The determinant of healthcare childbirth among young people in Indonesia. J. Publ. Health Res. 2021; 10, 1890.

[7] AD Laksono and RD Wulandari. The barrier to maternity care in rural Indonesia. J. Publ. Health 2020. doi:10.1007/s10389-020-01274-3.

[8] S Rahmadani, Marhania, MY Abadi, DS Marzuki, Sudirmanb and MA Fajrin. Analysis of independent national health insurance ownership of informal workers: Study of market traders in Gowa district, Indonesia. Enferm. Clin. 2020; 30, 295-9.

[9] RD Wulandari, AD Laksono and R Matahari. The effects of health insurance on maternity care in health services in Indonesia. Int. J. Innov. Creat. Change 2020; 14, 478-97.

[10] AD Laksono, RD Wulandari and O Soedirham. Regional disparities of health center utilization in rural Indonesia. Malaysian J. Publ. Health Med. 2019; 19, 158-66.

[11] A Kachikis, AB Moller, T Allen, L Say and D Chou. Equity and intrapartum care by skilled birth attendant globally: Protocol for a systematic review. BMJ Open 2018; 8, 019922.

[12] I Kusrini and AD Laksono. Regional disparities of stunted toddler in Indonesia. Indian J. Forensic Med. Toxicol. 2020; 14, 1685-91. 
[13] Ministry of Health of the Republic of Indonesia. Republic of Indonesia Minister of Health regulation number 99/2015 concerning health services at National Health Insurance. Ministry of Health of the Republic of Indonesia, Indonesia, 2015.

[14] RD Wulandari, S Supriyanto, MB Qomarrudin and AD Laksono. Socioeconomic disparities in hospital utilization among elderly people in Indonesia. Indian J. Publ. Health Res. Dev. 2019; 10, 1800-4.

[15] AD Laksono, R Rukmini and RD Wulandari. Regional disparities in antenatal care utilization in Indonesia. PLoS One 2020; 15, e0224006.

[16] RD Wulandari and AD Laksono. Urban-rural disparity: The utilization of primary health care center among elderly in East Java, Indonesia. Jurnal Administrasi Kesehatan Indonesia 2019; 7, 147-54.

[17] United Nations Group of Experts on Geographical Names. In: Proceedings of the $11^{\text {th }}$ United Nations Conference on the Standardization of Geographical Names, New York, 2017, p. 1-22.

[18] MH Yudhistira and Y Sofiyandi. Seaport status, port access, and regional economic development in Indonesia. Marit. Econ. Logist. 2018; 20, 549-68.

[19] I Indra, S Nazara, D Hartono and S Sumarto. Expenditure inequality and polarization in Indonesia, 2002 - 2012. Int. J. Soc. Econ. 2018; 45, 1469-86.

[20] R Mubasyiroh, E Nurhotimah and AD Laksono. Health service accessibility index in Indonesia (indeks aksesibilitas pelayanan kesehatan di Indonesia). In: S Supriyanto, D Chalidyanto and RD Wulandari (Eds.). Accessibility of health services in Indonesia (aksesibilitas pelayanan kesehatan di Indonesia) (in Indonesian). PT Kanisius, Jogjakarta, 2016, p. 21-58.

[21] T Afifah, MT Nuryetty, Cahyorini, DA Musadad, A Schlotheuber, N Bergen and R Johnston. Subnational regional inequality in access to improved drinking water and sanitation in Indonesia: Results from the 2015 Indonesian National Socioeconomic Survey (SUSENAS). Glob. Health Action 2018; 11, 1496972.

[22] PD Tyler, DJ Stone, BP Geisler, S McLennan, LA Celi and B Rush. Racial and geographic disparities in interhospital ICU transfers. Crit. Care Med. 2018; 46, e76-e80.

[23] M Rostami, M Karamouzian, A Khosravi and S Rezaeian. Gender and geographical inequalities in fatal drug overdose in Iran: A province-level study in 2006 and 2011. Spat. Spatiotemporal Epidemiol. 2018; 25, 19-24.

[24] S Momenyan, A Kavousi, J Poorolajal and N Momenyan. Spatial inequalities and predictors of HIV/AIDS mortality risk in Hamadan, Iran: A retrospective cohort study. Epidemiol. Health 2018; 40, e2018038.

[25] S Tourani, M Zarezadeh, M Raadabadi and F Pourshariati. Association of regional disparity of obstetrics and gynecologic services with children and infants mortality rates: A cross-sectional study. Int. J. Reprod. Biomed. 2017; 15, 147-54.

[26] C Alinia, SF Mohammadi, M Jabbarvand and H Hashemi. Geographical inequality in cataract surgery among Iranians between 2006 and 2011. East. Mediterr. Health J. 2018; 24, 664-71.

[27] M Qorbani, R Kelishadi, S Djalalinia, ME Motlagh, A Kasaeian, G Ardalan, G Shafiee, O Safari, R Heshmat and SB Mahdavi. Regional disparity in hygienic behaviors of Iranian children and adolescents: The CASPIAN-IV study. Med. J. Islam. Repub. Iran 2016; 30, 431.

[28] AA Sari, S Rezaei, EH Rad, N Dehghanian and Y Chavehpour. Regional disparity in physical resources in the health sector in Iran: A comparison of two time periods. Iran. J. Public Health 2015; 44, 848-54.

[29] ME Asar, R Varehzardi, GR Vasokolaei, M Haghi and M Fazelipor. Regional disparities in the distribution of healthcare workers: Evidence from Iran, Chaharmahal and Bakhtiari province. Glob. J. Health Sci. 2015; 7, 374-8.

[30] H Ravaghi, E Taati, Z Abdi, A Meshkini and S Sarvarizadeh. Factors influencing the geographic distribution of physicians in Iran: A qualitative study. Rural Rem. Health 2015; 15, 2967.

[31] B Gavurova, V Kovac and J Fedacko. Regional disparities in medical equipment distribution in the Slovak Republic - a platform for a health policy regulatory mechanism. Health Econ. Rev. 2017; 7, 39.

[32] TFX O’Donnell, C Powell, SE Deery, JD Darling, K Hughes, KA Giles, GJ Wang and ML Schermerhorn. Regional variation in racial disparities among patients with peripheral artery disease. J. Vasc. Surg. 2018; 68, 519-26.

[33] IG Song, SH Shin and HS Kim. Improved regional disparities in neonatal care by government-led policies in Korea. J. Korean Med. Sci. 2018; 33, e43. 
[34] S Chung, RJ Romanelli, CD Stults and HS Luft. Preventive visit among older adults with Medicare's introduction of Annual Wellness Visit: Closing gaps in underutilization. Prev. Med. 2018; 115, 110-8.

[35] AM Nigatu, KA Gelaye, DT Degefie and AY Birhanu. Spatial variations of women's home delivery after antenatal care visits at lay Gayint District, Northwest Ethiopia. BMC Publ. Health 2019; 19, 677.

[36] LS Dadi, M Berhane, Y Ahmed, EK Gudina, T Berhanu, KH Kim, M Getnet and M Abera. Maternal and newborn health services utilization in Jimma Zone, Southwest Ethiopia: A community based cross-sectional study. BMC Pregnancy Childbirth 2019; 19, 178.

[37] Z Baraki, F Wendem, H Gerensea and H Teklay. Husbands involvement in birth preparedness and complication readiness in Axum town, Tigray region, Ethiopia, 2017. BMC Pregnancy Childbirth $2019 ; 19,180$.

[38] FP Senewe and E Elsi. Descriptive analysis to environment health in less development, borderlands, archipelagoes and remote areas (DTPK-T). Media Litbangkes 2014; 24, 153-60.

[39] Suharmiati, AD Laksono and WD Astuti. Policy review on health services in primary health center in the border and remote area (Review Kebijakan tentang Pelayanan Kesehatan Puskesmas di Daerah Terpencil Perbatasan). Bull. Health Syst. Res. 2013; 16, 109-16.

[40] AD Laksono, R Mubasyiroh, T Laksmiarti, E Nurhotimah, Suharmiati and NE Sukoco. Healthcare Accessibility in Indonesia (Aksesibilitas Pelayanan Kesehatan di Indonesia) (in Indonesian). PT Kanisius, Jogjakarta, 2016.

[41] P Boontem, P Suthamma and N Jurakarn. The effectiveness of life skills program on life skills to prevent risky sexual behaviours in primary school students, Thailand. Walailak J. Sci. Tech. 2019; 16, 545-50.

[42] RD Wulandari and AD Laksono. Are problems during pregnancy a predictor of childbirth in the hospital? Determinants analysis of hospital childbirth in urban poor communities in Indonesia. Indian J. Forensic Med. Toxicol. 2020; 14, 3262-7.

[43] RD Wulandari and AD Laksono. Determinants of knowledge of pregnancy danger signs in Indonesia. PLoS One 2020; 15, e0232550.

[44] RD Wulandari and AD Laksono. Education as predictor of the knowledge of pregnancy danger signs in rural Indonesia. Int. J. Innov. Create. Change 2020; 13, 1037-51.

[45] M Ipa, M Widawati, AD Laksono, I Kusrini and PW Dhewantara. Variation of preventive practices and its association with malaria infection in eastern Indonesia: Findings from community-based survey. PLoS One 2020; 15, e0232909.

[46] H Megatsari, AD Laksono, M Ibad, YT Herwanto, KP Sarweni, RAP Geno and E Nugraheni. The community psychosocial burden during the COVID-19 pandemic in Indonesia. Heliyon 2020; 6, e05136.

[47] AA Seran, MD Antaria, S Haksama, E Setijaningrum, AD Laksono and ADP Sujoso. Disparities of the use of hormonal and non-hormonal contraceptive drugs in urban and rural areas in Indonesia and the world. Syst. Rev. Pharm. 2020; 11, 66-73.

[48] N Rohmah, A Yusuf, R Hargono, AD Laksono, Masruroh, I Ibrahim and S Walid. Determinants of teenage pregnancy in Indonesia. Indian J. Forensic Med. Toxicol. 2020; 14, 2080-5.

[49] Q Andayani, T Koesbardiati, AD Sujoso, Masruroh and AD Laksono. the barrier to access health insurance for maternity care: Case study of female workers in Indonesia. Med. Legal Update 2021; 21, 926-32.

[50] Masruroh, A Yusuf, N Rohmah, IB Pakki, ADP Prasojo, Q Andayani and AD Laksono. Neonatal death incidence in healthcare facility in Indonesia: Does antenatal care matter? Indian J. Forensic Med. Toxicol. 2021; 15, 1265-71.

[51] J Mullerschon, C Koschollek, C Santos-Hovener, A Kuehne, Müller-Nordhorn J and V Bremer. Impact of health insurance status among migrants from sub-Saharan Africa on access to health care and HIV testing in Germany: A participatory cross-sectional survey. BMC Int. Health Hum. Rights 2019; 19, 10.

[52] F Efendi, AR Ni'Mah, S Hadisuyatmana, H Kuswanto, L Lindayani and SM Berliana. Determinants of facility-based childbirth in Indonesia. Sci. World J. 2019; 2019, 9694602.

[53] ZK Nantabah, ZA Auliyati and AD Laksono. Overview of health services access for toddlers in Indonesia. Bull. Health Syst. Res. 2019; 22, 54-61. 